\title{
Innovative education approaches by geriatric pharmacists and their training needs: A systematic review
}

\author{
Yuhansyah Nurfauzi,1,2, Djoko Wahyono ${ }^{3 *}$, Fita Rahmawati ${ }^{3}$, Nanang Munif \\ Yasin ${ }^{3}$ \\ ${ }^{1}$ Doctoral Program in Pharmaceutical Science, Faculty of Pharmacy, Gadjah Mada University, Yogyakarta, ${ }^{2}$ Department of \\ Pharmacy, STIKES Al-Irsyad Al-Islamiyyah, Cilacap, ${ }^{3}$ Department of Pharmacology and Clinical Pharmacy, Gadjah Mada \\ University, Yogyakarta, Indonesia
}

*For correspondence: Email: djokowahyono@ugm.ac.id, Tel: +62811261953

Sent for review: 5 March 2019

Revised accepted: 20 June 2020

\begin{abstract}
Purpose: To undertake a systematic review designed to observe the educational activities carried out by geriatric pharmacists innovatively, and also to ascertain their training needs.

Methods: Articles were selected based on the following inclusion criteria: published in the years 2000 2019, designed as a randomized controlled trial (RCT), published in English language, contained educational activities carried out by pharmacists, and contained training requirements for pharmacists. The exclusion criteria were as follows: did not mention educational activities, only examined and assessed economic aspects, and used qualitative studies. This study analyzed nine articles from PUBMED, Scopus and Google Scholar that met the inclusion criteria.

Results: Comprehensive education consisting of approaches such as interviews, discussions, case conferences, demonstrations, and goal-setting techniques provided innovations to medication review and pharmaceutical care plans. Seminar and e-learning were approaches to innovative problem-based education. Pharmacists needed training on medication review, education techniques for geriatrics, clinical collaboration, and geriatric pharmacotherapy.

Conclusion: Pharmacist chose comprehensive and problem-based education approaches innovatively which require training in treatment management as well as professional relationship skills as educators, and based on the perspective of elderly needs.
\end{abstract}

Keywords: Geriatric, Pharmacist, Education, Training, Innovative approaches

\begin{abstract}
This is an Open Access article that uses a fund-ing model which does not charge readers or their institutions for access and distributed under the terms of the Creative Commons Attribution License (http://creativecommons.org/licenses/by/4.0) and the Budapest Open Access Initiative (http://www.budapestopenaccessinitiative.org/read), which permit unrestricted use, distribution, and reproduction in any medium, provided the original work is properly credited.
\end{abstract}

Tropical Journal of Pharmaceutical Research is indexed by Science Citation Index (SciSearch), Scopus, International Pharmaceutical Abstract, Chemical Abstracts, Embase, Index Copernicus, EBSCO, African Index Medicus, JournalSeek, Journal Citation Reports/Science Edition, Directory of Open Access Journals (DOAJ), African Journal Online, Bioline International, Open-J-Gate and Pharmacy Abstracts

\section{INTRODUCTION}

Geriatric pharmacy is a specialty of the pharmacy profession that has gradually developed as a result of the steady increase in the elderly population. A geriatric pharmacist is part of a multidisciplinary team that, together with other health professionals, provides health services to the elderly, especially in geriatric pharmacotherapy. An optimal service model for comprehensive care for older adults can consist of geriatric pharmacists, gero-psychiatrists, and geriatric-trained social workers who collaborate with nurses and doctors. Such comprehensive 
services, including those carried out by geriatric pharmacists, can be carried out in various locations, such as institutions, communities, and patient homes [1].

A prominent activity in geriatric pharmacotherapy is continuing education. Educational activities provided by the geriatric pharmacist can be directed toward patients, doctors, nurses, and other pharmacists. Canada, the United States, the United Kingdom, and Ireland have developed academic detailing as a form of education from pharmacists for doctors in the context of optimizing drug services for the elderly. In these countries, education through academic detailing provides promising results for improving medication prescriptions from doctors for the elderly [2-4]. Educational activities that are needed and can be done by pharmacists in other forms include the provision of information on contraindications and drug interactions for the elderly seeking non-prescription drugs in pharmacies [5]. Other educational efforts have been carried out by pharmacists, together with the relevant teams, in the context of home care to the elderly as a form of activity that benefits the latter [6].

The pharmacist's need for educational skills in providing services to the elderly cannot be separated from the training they obtained. Although many pharmacists teach or provide education, most do not have formal training in teaching [7]. Training highlights the need for pharmacists to grow and develop in their performance through sustainable learning. The participation of pharmacists in training also shows creative efforts to support the development of their abilities and competencies [8]. Pharmacists as educators are expected to provide optimal education to the elderly through adequate training. Although much research has adopted this perspective, no systematic review that specifically evaluates various aspects of innovation in educational activities and training needs is yet available.

Thus, the present systematic review is designed to observe innovative educational activities carried out by geriatric pharmacists in geriatric pharmacotherapy studies and assess the training needed.

\section{METHODS}

This systematic review involved studies related to education and training in pharmacist activities when providing pharmaceutical services to the elderly.

\section{Study identification}

This systematic review sought original articles describing innovative practices through an educational approach as a form of intervention by pharmacists as well as additional training needed by the pharmacist. The articles were selected according to several inclusion criteria: published in the years 2000-2019, designed as a randomized controlled trial (RCT), published in the English language, contains educational activities by pharmacists, and contains training requirements for pharmacists.

The exclusion criteria were as follows: did not mention educational activities, only examined and assessed economic aspects, and used qualitative study design even though the study used secondary data from RCT research. Three electronic databases, namely, PUBMED, Scopus and Google Scholar, were searched in May 2019. The search terms used are summarized in Table 1. Additional articles were identified through reference tracking.

Table 1: Search terms used to identify relevant studies

\begin{tabular}{|c|c|}
\hline Database & Search terms \\
\hline $\begin{array}{l}\text { PUBMED } \\
(2000-2019)\end{array}$ & $\begin{array}{l}\text { "Health Services for the } \\
\text { Aged"[Mesh] OR "Health Services } \\
\text { for the Aged"[tw] OR"Geriatric } \\
\text { Health Services"[tw] OR"Health } \\
\text { Services for the Elderly"[tw] } \\
\text { OR"Health Services, Geriatric"[tw] } \\
\text { OR"Geriatric Health Service"[tw] } \\
\text { OR"Health Service, Geriatric"[tw] } \\
\text { OR"Service, Geriatric Health"[tw] } \\
\text { OR"Services, Geriatric Health"[tw] } \\
\text { OR"Health Services for Aged"[tw] } \\
\text { AND "Pharmaceutical } \\
\text { Services"[Mesh] OR } \\
\text { "Pharmaceutical Services"[tw] } \\
\text { OR"Services, Pharmaceutic"[tw] } \\
\text { OR"Services, Pharmacy"[tw] } \\
\text { OR"Pharmaceutic Services"[tw] } \\
\text { OR"Pharmaceutic Service"[tw] } \\
\text { OR"Service, Pharmaceutic"[tw] } \\
\text { OR"Services, Pharmaceutical"[tw] } \\
\text { OR"Pharmaceutical Service"[tw] } \\
\text { OR"Service, Pharmaceutical"[tw] } \\
\text { OR"Pharmacy Services"[tw] } \\
\text { OR"Pharmacy Service"[tw] } \\
\text { OR"Service, Pharmacy"[tw] } \\
\text { OR"Pharmaceutical Care"[tw] } \\
\text { OR"Care, Pharmaceutical"[tw] }\end{array}$ \\
\hline $\begin{array}{l}\text { Scopus } \\
(2000-2019)\end{array}$ & $\begin{array}{l}\text { "Health Services for the } \\
\text { Aged"AND "Pharmaceutical } \\
\text { Services" }\end{array}$ \\
\hline $\begin{array}{l}\text { Google } \\
\text { Scholar } \\
(2000-2019)\end{array}$ & $\begin{array}{l}\text { "Health Services for the Aged" } \\
\text { AND "Pharmaceutical Services" }\end{array}$ \\
\hline
\end{tabular}

Trop J Pharm Res, July 2020; 19(7): 1526 


\section{Screening and assessment of selected studies}

The complete process from evaluating articles generated from the database searches to producing the selected articles is shown in Figure 1.

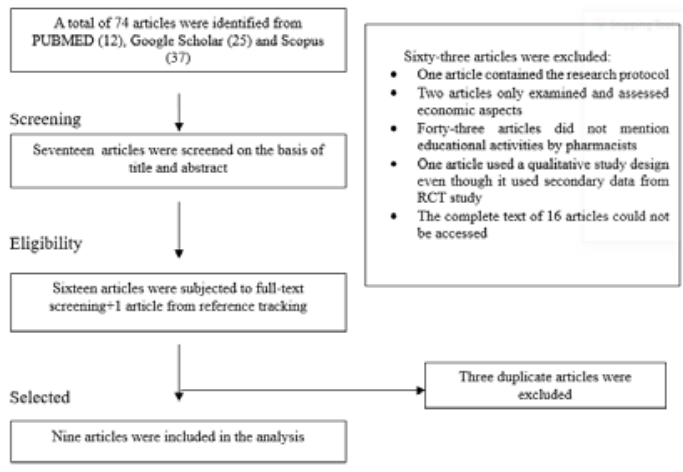

Figure 1: Prisma diagram of the retrieved studies

This systematic review was designed to reveal various approaches used in educational activities carried out by pharmacists and additional training needs. Innovative approaches to implement education can produce diverse outcomes, and identify training needs for pharmacists. Therefore, the researchers applied clear inclusion and exclusion criteria to screen the results of each study to fit the purpose of this systematic review. Screening of title, abstract, and full text was applied to the selected studies. An important inclusion criterion is that the study must have an RCT design so that interventions carried out by pharmacists, which represents innovative approaches to education and training, could be revealed. The data of the studies were extracted independently by the researchers using a data extraction form to reveal approaches in education and training efforts.

\section{Data extraction}

The setting, interventions, form of education, aspect of training needed, and approach adopted were extracted independently from each study using data extraction form.

\section{RESULTS}

As shown in Figure 1, electronic database searches produced a total of 74 articles from PUBMED (12), Google Scholar (25), and Scopus (37). A total of 63 articles were considered unsuitable for this review according to the exclusion criteria. One additional article was taken from a reference search of one of the included articles. Three duplicate articles were excluded. Finally, nine articles were included in this review.

\section{Characteristics of the selected studies}

The studies included in this review were published in the United States, United Kingdom, Scotland, Sweden, Netherlands, Ireland, Australia, and Singapore. All articles involved studies with an RCT design. An RCT study design allows the researchers to determine the intervention provided so that detection of educational efforts can be done quickly. In general, the involvement of pharmacists revealed in the intervention provided in the form of pharmaceutical services specifically for elderly patients. The involvement of pharmacists in the study interventions is also a source of information on educational activities.

Educational interventions can be done on patients, doctors, and nurses, while training is conducted by pharmacists on other pharmacists. Pharmacists have two patterns of need for training to be able to innovate, namely treatment management (Table 2) and professional relationships (Table 3 ).

According to the results of the present review, two innovation based on the pharmacist approach are involved in providing education: comprehensive education and problem-based education. Educational approaches that appear in comprehensive education are applied to patients and their families through medication review and pharmaceutical care plan (PCP) activities. These approaches include interviews, discussions, case conferences, demonstrations, and goal setting techniques [10-16]. Educational approaches applied to problem-based education are applied to nurses and doctors through clinical pharmacy activities. These approaches include seminars and e-learning about potentially inappropriate medications in the elderly $[9,17]$. Geriatric pharmacists need training in medication review $[9,10,13]$, educational techniques for the elderly $[10,11,15]$, clinical collaboration [16] and geriatric pharmacotherapy $[9,12-14,17]$.

\section{DISCUSSION}

\section{Innovative education approaches}

The studies included in the present review feature various settings such as a nursing home, hospital, primary care, and community pharmacies. Research on nursing homes conducted in Australia revealed a pharmacist's struggle to change nursing services with the 
active participation of the nurses themselves. Nurses needed education from the pharmacist about medications related to long-term care. The main problems of the elderly could be solved by medication, and these needs were addressed by nurses. Nurses needed more insights into drug use in the elderly; however, when this study was conducted in Australia, clinical pharmacy services had not yet been implemented at the nursing homes involved. Thus, nurses at the nursing homes requested education from pharmacists and were actively involved in applying learning outcomes. Medicines that had been reviewed by pharmacists became educational material in seminars for nurses. This seminar approach is a form of innovation from problem-based education. Providing clinical pharmacy services through a facilitated focus group approach represents a model that must be introduced to pharmacists before they can provide education to nurses in nursing homes [9]. Other service characteristics may be observed in pharmacist interventions with hospital settings. Hospital pharmacists were more likely to carry out educational activities, together with the geriatric team, as a service development activity in outpatient clinics [11] and during hospitalization until the patient is discharged from the hospital; such activities may even continue when the patient returns home [15].

Table 2: Characteristics of the selected studies with treatment management training need

\begin{tabular}{|c|c|c|c|c|c|}
\hline $\begin{array}{c}\text { Innovation, } \\
\text { Year }\end{array}$ & Setting & Intervention & Education Form & $\begin{array}{l}\text { Training } \\
\text { Needed }\end{array}$ & Approach \\
\hline $\begin{array}{l}\text { Problem- } \\
\text { based } \\
\text { education } \\
\text { with clinical } \\
\text { pharmacy } \\
\text { activities, } \\
2001[9]\end{array}$ & $\begin{array}{l}\text { The pioneer } \\
\text { in clinical } \\
\text { pharmacy } \\
\text { activities in } \\
\text { Australia } \\
\text { nursing } \\
\text { homes }\end{array}$ & $\begin{array}{l}\text { The clinical } \\
\text { pharmacy } \\
\text { service model } \\
\text { consists of } \\
\text { three phases: } \\
\text { recognition of } \\
\text { the clinical } \\
\text { pharmacy } \\
\text { activities, } \\
\text { education to } \\
\text { nurses, and } \\
\text { medication } \\
\text { review by } \\
\text { clinical } \\
\text { pharmacists }\end{array}$ & $\begin{array}{l}\text { Basic geriatric } \\
\text { pharmacology; } \\
\text { common } \\
\text { problems in the } \\
\text { elderly people } \\
\text { who undergo } \\
\text { long-term care }\end{array}$ & $\begin{array}{l}\text { Medication } \\
\text { review and } \\
\text { geriatric } \\
\text { pharmacotherapy }\end{array}$ & $\begin{array}{l}\text { Seminar to nurses } \\
\text { and education to } \\
\text { the doctor about } \\
\text { potentially } \\
\text { inappropriate } \\
\text { medications }\end{array}$ \\
\hline $\begin{array}{l}\text { Comprehensi } \\
\text { ve education } \\
\text { in medication } \\
\text { review and } \\
\text { pharmaceutic } \\
\text { al care plan } \\
(\mathrm{PCP}), 2001 \\
{[10]}\end{array}$ & $\begin{array}{l}\text { Pharmacist- } \\
\text { led } \\
\text { medication } \\
\text { review in } \\
\text { Scotland }\end{array}$ & $\begin{array}{l}\mathrm{PCP} \text { and } \\
\text { medication } \\
\text { review }\end{array}$ & $\begin{array}{l}\text { Education about } \\
\text { special drugs } \\
\text { such as inhalers } \\
\text { and provision of } \\
\text { information about } \\
\text { drugs needed by } \\
\text { patients }\end{array}$ & $\begin{array}{l}\text { Medication } \\
\text { review and } \\
\text { techniques for } \\
\text { using drugs with } \\
\text { special dosage } \\
\text { forms }\end{array}$ & $\begin{array}{l}\text { Home visits to } \\
\text { patients }\end{array}$ \\
\hline $\begin{array}{l}\text { Comprehensi } \\
\text { ve education } \\
\text { on PCPs, } \\
2004 \text { [11] }\end{array}$ & $\begin{array}{l}\text { Hospital- } \\
\text { based } \\
\text { geriatric } \\
\text { outpatient } \\
\text { clinic, } \\
\text { Singapore }\end{array}$ & $\begin{array}{l}\text { Consultation } \\
\text { by the } \\
\text { pharmacist to } \\
\text { the patient }\end{array}$ & $\begin{array}{l}\text { Knowledge of } \\
\text { drug indications; } \\
\text { techniques to } \\
\text { administer } \\
\text { special drugs, } \\
\text { such as inhalers } \\
\text { and insulin; } \\
\text { knowledge of } \\
\text { disease issues } \\
\text { and non- } \\
\text { compliance } \\
\text { strategies }\end{array}$ & $\begin{array}{l}\text { Provision of } \\
\text { counseling, } \\
\text { information on } \\
\text { treatment } \\
\text { management,, } \\
\text { and education to } \\
\text { patients and their } \\
\text { families }\end{array}$ & $\begin{array}{l}\text { Interviews, } \\
\text { discussions, } \\
\text { specific counseling } \\
\text { and demonstrations }\end{array}$ \\
\hline $\begin{array}{l}\text { Comprehensi } \\
\text { ve education } \\
\text { in medication } \\
\text { review, } \\
2007[12]\end{array}$ & $\begin{array}{l}\text { A large } \\
\text { health } \\
\text { maintenance } \\
\text { organization, } \\
\text { Seattle, } \\
\text { Washington, } \\
\text { United } \\
\text { States }\end{array}$ & $\begin{array}{l}\text { Pharmacists } \\
\text { are part of the } \\
\text { geriatric team } \\
\text { to improve } \\
\text { geriatric } \\
\text { services }\end{array}$ & $\begin{array}{l}\text { Education } \\
\text { about knowledge } \\
\text { of psychoactive } \\
\text { medications by } \\
\text { geropharmacist; } \\
\text { the pharmacist } \\
\text { team educates } \\
\text { patients about } \\
\text { treatment }\end{array}$ & $\begin{array}{l}\text { Recognition of } \\
\text { medications that } \\
\text { need to be } \\
\text { monitored for the } \\
\text { elderly; } \\
\text { communication } \\
\text { techniques to } \\
\text { patients via } \\
\text { telephone }\end{array}$ & $\begin{array}{l}\text { Goal-setting } \\
\text { techniques for the } \\
\text { pharmacist team } \\
\text { and phone } \\
\text { interviews to } \\
\text { patients }\end{array}$ \\
\hline
\end{tabular}


Table 3: Characteristics of the selected studies with professional relationship training need

\begin{tabular}{|c|c|c|c|c|c|}
\hline $\begin{array}{c}\text { Innovation, } \\
\text { Year }\end{array}$ & Setting & Intervention & $\begin{array}{l}\text { Education } \\
\text { Form }\end{array}$ & $\begin{array}{l}\text { Training } \\
\text { Needed }\end{array}$ & Approach \\
\hline $\begin{array}{l}\text { Comprehensi } \\
\text { ve education } \\
\text { in medication } \\
\text { review and } \\
\text { PCP, } \\
2007[13]\end{array}$ & $\begin{array}{l}\text { General } \\
\text { practices } \\
\text { and } \\
\text { community } \\
\text { pharmacies, } \\
\text { Netherland }\end{array}$ & $\begin{array}{l}\mathrm{PCP} \text { and } \\
\text { medication } \\
\text { review }\end{array}$ & $\begin{array}{l}\text { Education } \\
\text { about drugs to } \\
\text { doctors, such as } \\
\text { dosages, } \\
\text { indications, } \\
\text { contraindications, } \\
\text { dosage forms, } \\
\text { drug interactions, } \\
\text { and duration of } \\
\text { treatment }\end{array}$ & $\begin{array}{l}\text { Drug-related } \\
\text { problems, } \\
\text { completion, and } \\
\text { medication } \\
\text { review }\end{array}$ & $\begin{array}{l}\text { An educational } \\
\text { approach to } \\
\text { doctors through } \\
\text { case conferences } \\
\text { and written } \\
\text { feedback }\end{array}$ \\
\hline $\begin{array}{l}\text { Comprehensi } \\
\text { ve education } \\
\text { in medication } \\
\text { review, } 2013 \\
\text { [14] and } 2009 \\
\text { [15] }\end{array}$ & $\begin{array}{l}\text { Uppsala } \\
\text { University } \\
\text { Hospital, } \\
\text { Sweden }\end{array}$ & $\begin{array}{l}\text { Drug } \\
\text { reconciliation, } \\
\text { medication } \\
\text { review, } \\
\text { further action } \\
\text { on drug } \\
\text { changes, } \\
\text { patient } \\
\text { education, } \\
\text { communicatio } \\
\text { n of treatment } \\
\text { plans and } \\
\text { follow-up }\end{array}$ & $\begin{array}{l}\text { Education } \\
\text { from the clinical } \\
\text { pharmacists for } \\
\text { health care } \\
\text { teams with a } \\
\text { focus and } \\
\text { knowledge about } \\
\text { drug prescribing } \\
\text { for the elderly as } \\
\text { well as education } \\
\text { about drug } \\
\text { therapy received } \\
\text { to patients. }\end{array}$ & $\begin{array}{l}\text { Application of } \\
\text { criteria for } \\
\text { appropriate } \\
\text { prescription of } \\
\text { drugs for the } \\
\text { elderly and } \\
\text { education for } \\
\text { doctors as well } \\
\text { as provision of } \\
\text { motivation to } \\
\text { patients during } \\
\text { drug counselling }\end{array}$ & $\begin{array}{l}\text { Demonstration of } \\
\text { the quality of } \\
\text { prescription, } \\
\text { focusing not only } \\
\text { on the accuracy of } \\
\text { treatment but also } \\
\text { the assessment of } \\
\text { patient needs with } \\
\text { semi-structured } \\
\text { interviews }\end{array}$ \\
\hline $\begin{array}{l}\text { Comprehensi } \\
\text { ve education } \\
\text { in medication } \\
\text { review and } \\
\text { PCP, } 2010 \\
\text { [16] }\end{array}$ & $\begin{array}{l}\text { Five primary } \\
\text { care trusts, } \\
\text { United } \\
\text { Kingdom }\end{array}$ & $\begin{array}{l}\text { Pharmaceutical } \\
\text { services }\end{array}$ & $\begin{array}{l}\text { Education } \\
\text { related to } \\
\text { pharmaceutical } \\
\text { care processes, } \\
\text { such as providing } \\
\text { information about } \\
\text { the indications of } \\
\text { drug }\end{array}$ & $\begin{array}{l}\text { Pharmaceutical } \\
\text { care theory and } \\
\text { practice, training } \\
\text { and collaboration } \\
\text { with doctors, } \\
\text { methods to } \\
\text { involve patients } \\
\text { and other service } \\
\text { providers }\end{array}$ & $\begin{array}{l}\text { Cooperation with } \\
\text { doctors, patients } \\
\text { and other service } \\
\text { providers in } \\
\text { designing, } \\
\text { implementing and } \\
\text { monitoring } \\
\text { pharmaceutical } \\
\text { services up to } \\
\text { home visits }\end{array}$ \\
\hline $\begin{array}{l}\text { Problem- } \\
\text { based } \\
\text { education, } \\
2017[17]\end{array}$ & $\begin{array}{l}\text { Six public } \\
\text { hospitals, } \\
\text { southern } \\
\text { region of } \\
\text { Ireland }\end{array}$ & $\begin{array}{l}\text { E-learning } \\
\text { with } \\
\text { educational } \\
\text { modules }\end{array}$ & $\begin{array}{l}\text { Education of } \\
\text { prescription } \\
\text { criteria for } \\
\text { doctors to reduce } \\
\text { inappropriate } \\
\text { drugs for the } \\
\text { elderly }\end{array}$ & $\begin{array}{l}\text { Application of } \\
\text { criteria for } \\
\text { appropriate } \\
\text { prescription of } \\
\text { drugs for the } \\
\text { elderly and } \\
\text { education for } \\
\text { doctors }\end{array}$ & $\begin{array}{l}\text { Coordination and } \\
\text { networking services } \\
\text { with institutions and } \\
\text { families of patients }\end{array}$ \\
\hline
\end{tabular}

While in the hospital, pharmacist may involve doctors, especially those appropriately prescribing criteria for the elderly $[14,17]$. In pharmacy service settings within primary care, followed by service at the patient's home, pharmacists can act as initiators in providing education to patients but still collaborate with doctors and nurses $[10,13,16]$.

A pharmaceutical service setting with educational activities as part of complex interventions is adapted to primary care. In this model, pharmacy services are also associated with community pharmacies and patient homes. The intended intervention is the application of the PCP. Education on this type of intervention is an integral part of and has been integrated to pharmaceutical service standards. For example, research in the UK included pharmaceutical care services in the primary care system [16]. The clinician or general practitioner as another form of primary care provider is also a pharmacy service setting for pharmacists to develop educational activities needed, both for elderly patients and health workers with PCP models.

The interventions of the studies described in this review mainly include well-known pharmaceutical service models. Nevertheless, these practices require innovation with new techniques developed by pharmacists with specific settings. The mention of the form of intervention from a collaborative perspective is in a study from the USA.This study indicated that pharmacists intervene in a geriatric interdisciplinary team to improve the service focus for elderly patients who also contained medication review activities [12]. Therefore, terms such as clinical pharmacy, 
PCP, medication review and pharmacist consultation dominate the intervention model of the study obtained $[9-11,13,16]$. However, there is also a form of education that is mentioned in more detail, such as drug reconciliation and the sequence that contains activities similar to pharmaceutical care $[14,15]$.

The form of education in clinical pharmacy models main involves basic geriatric pharmacology and general problems among the elderly undergoing long-term care with drugs. Both forms of education are provided by pharmacists to nurses in the nursing home with the aim of reducing drug use among the elderly [9]. Education is provided to nurses in nursing homes in the form of seminars or problem-based education. This form of education requires media such as wall charts and bulletins.

When creating a PCP, the pharmacist may first create a list of actual and potential drug-related problems. Next, the pharmacist plans the desired results and suggests actions to achieve the desired outcomes. The plan is then submitted to the doctor for approval and carried out by the pharmacist together with the parties concerned [10]. The forms of PCP education can vary depending on the patient's specific needs; providing information on the use of drug with a special dosage form (inhaler), for example, may be necessary for some patients but not for others. Varying patient needs will require variations in educational activities, such as education on drug indications [16]. Doctors can be provided education on drugs by pharmacists in PCP [13]. Consultation with various examples of forms of education is also a method for delivering education about drugs from pharmacists to patients in the context of PCP [11].

E-learning with educational modules is a novel intervention. Clinical pharmacists act as assessors when creating online modules together with geriatric consultants. Online modules are an educational medium that focuses on geriatric pharmacotherapy for doctors. The pharmacist also trains doctors on the use of the Beer criteria or other related screening tools, such as the Screening Tool of Older Person's Prescriptions (STOPP) and the Screening Tool to Alert Doctors to Right Treatment (START), to avoid potentially inappropriate prescribing. Therefore, this intervention model can optimize the appropriate prescription of drugs to the elderly [17].

Research that positions pharmaceutical services as a component of the health team also shows that the education to be conducted by pharmacists requires a suitable collaborative approach. Collaboration with doctors and the patient's family is of great importance $[13,14,16,17]$. Thus, the participation of pharmacists in collaborative health service systems for the elderly is essential. Clinical pharmacists can provide innovative education, together with various other activities, such as drug reconciliation, medication review, verbal delivery of the results of medication reviews to doctors, designing follow-up on changes in patient medication, communication of treatment plans, and follow-up by telephone to the patient after discharge. The results of these activities indicate that the presence of pharmacists increases the appropriate prescription of patients when measured by the Medication Appropriateness Index (MAI), STOPP, and START criteria [14].

Comprehensive pharmacy services for the elderly with good communication and collaboration approaches can potentially improve outcomes when connected from the hospital to the patient's home. When an elderly patient is admitted to the hospital, the pharmacist can be involved in patient education by providing discussions related to drugs to patients and their families [15]. This activity is an innovative effort because it shows that the education that will be provided by the pharmacist is actively sought based on extracting the problem according to the patient's perspective. Such education continues from the time a patient is hospitalized until discharge from the hospital with counseling by the pharmacist. The benefits obtained include reduced hospital visits, increased patient knowledge and adherence to therapy, and reduced medication errors $[14,15]$. Other benefits for the elderly related to the reduction of potential and actual side effects are mentioned by two studies with settings in patients' homes and hospital outpatient clinics $[10,11]$.

Other innovative approaches that emerged from one of the studies in this review included case conference activities. This activity is carried out by pharmacists, who discuss all treatment recommendations for elderly patients with doctors; other matters that must be considered by patients are also considered. As a result, patients who received services from doctors provided education by pharmacists in the form of case conferences experienced more meaningful treatment changes compared with other methods (e.g., written recommendations) [13]. The innovation of pharmacists discussing their patients with doctors plays an important role in case conferences because many clinical 
recommendations from pharmacists have been successfully applied by doctors to elderly patients.

\section{Training needs of pharmacists}

The aforementioned approaches identified the training needs of pharmacists providing drugs to the elderly. Specific training can be obtained so that pharmacists can specialize in the geriatric field. One of the reviewed studies referred to a pharmacist with expertise with geriatric training as a geropharmacist. Geropharmacists play an important role in the senior resource team (SRT), which also consists of a geriatrician and registered nurse practitioners; they review the drug lists of elderly patients and provide nurses with recommendations. Some drugs used by the elderly, including psychoactive groups (e.g., benzodiazepines, skeletal muscle relaxants and medication with anticholinergic side effects), a special concern among geropharmacists.

The geropharmacist in an SRT must give other pharmacists who are members of the primary care provider team briefings [12]. These roles show the two-pronged approach to educational activities carried out by geropharmacists:care providers must not only provide recommendations to be carried out by nurses but also conduct briefings to other pharmacists so that services become synchronous.

This review found that not all pharmacists involved in pharmacy services for the elderly have a special designation. These pharmacists are generally referred to as clinical pharmacists or pharmacists working in teams. The reviewed studies showed that pharmacists in this category still need training when they wish to apply specific pharmaceutical services to the elderly. Three studies described primary care settings that provide special training for pharmacists to help them act as educators. One of the studies found that pharmacists in the community received training on the theory and practice of pharmaceutical care and collaborated with doctors to involve patients and caregiver to build, implement and monitor PCP [16]. Another study revealed that pharmacists are provided with special training in managing drug-related problems and medication reviews[13]. Another group of pharmacists received a briefing from the geropharmacist to obtain a better awareness of the use of psychoactive drugs in the elderly [12].

Innovative educational efforts were carried out by many pharmacists in the reviewed studies. Because the context of pharmaceutical services to the elderly is quite complex, including educational activities in various intervention models is necessary to improve outcomes. Education can be included in interventions such as medication reviews, PCPs, and clinical pharmacy activities. The development of new forms of education, such as e-learning, indicates that education needs will continue to grow as demands for professionalism in elderly health services increase. In this case, the object of education is the patient and pharmacists act as reliable educators. Therefore, it is appropriate for the ability to provide education to get the attention of the pharmacists themselves as well as from relevant parties with an interest in the professionalism of the pharmacist.

This systematic review revealed that a medication review is an example of an intervention model consisting of various service components, one of which is education. This finding is consistent with the perspective that a medication review is a form of service or intervention of which health education is one component $[18,19]$. Education can be conducted by pharmacists carrying out medication reviews and can also be done by other pharmacists, not by pharmacists who carry out medication reviews. Therefore, education as a component of medication review can vary in form according to the patient's condition, the medication required, and the service setting.

Training needs must be adjusted to the patient's perspective and not only focus on the drug. Some examples of training for pharmacists can be directly linked to restricted drugs, such as psychoactive drugs. However, the ability of pharmacists to explore the problems of the elderly with great precision and motivate the elderly also requires skills that can be enhanced by training. This consideration will be useful for academics who wish to develop a training curriculum for pharmacists in the field of geriatric pharmacology.

The need to monitor drug use may also be related to a patient's perspective. Some cardiovascular drugs, such as calcium channel blockers, diuretics and ACE inhibitors, have potential side effects if not accompanied by adequate monitoring. Special dosage forms, such as inhalers and insulin, are potential drugs for education [10]. Insulin use by the elderly is an example of the integration of some aspects of compliance with drug use from a complete perspective. Optimal adherence to the use of insulin and favorable outcomes are the result of consultation with not just elderly patients who have diabetes but also the persons who regulate 
their medication, such as pharmacists and family members [20].

Pharmacist training needs for the introduction of these special drugs need to be raised in a curriculum designed to educate them. Pharmacists need training on important findings related to essential instruments to understand the criteria for appropriate prescribing so that it becomes a valuable capital to provide education to doctors who handle the elderly. These criteria vary and can be chosen on the basis of the appropriate conditions, such as the Beers criteria, MAI, STOPP and START.

Innovative approaches are closely related to communication and collaboration skills and the ability of pharmacists tonetwork. Home visits and case conferences are potential methods and effective approaches in educational activities. The home visit allows focus on patient needs, while case conferences enhance the understanding of doctors. Drug reconciliation activities can be combined with medication reviews, and education through home care can be conducted to enable pharmacists to arrange comprehensive services from the hospital to the homes of elderly patients. Home care also provides a potential innovation for pharmacists to establish networks with elderly patient families or caregivers.

The results of this review should be viewed in light of some limitations. The present work is based on studies with an RCT design published in developed countries because RCT studies relevant to the theme of this review are scarce in developing countries. Pharmacists in developing countries must also understand educational activities because the elderly population increases evenly regardless of geography. An approach such as home care is strongly recommended by the World Health Organization for various countries with community-based service models, especially in developing countries [21,22]. Academic detailing or case conferences have been carried out in various countries as part of primary care $[3,4,13,23,24]$. Because the approaches discussed in this review are universal, they can be extended to developing countries in the context of existing services.

\section{CONCLUSION}

Pharmacists chose the comprehensive and problem-based education innovatively so that it requires training in treatment management with professional relationship skills as educators based on the perspective of elderly needs.

\section{DECLARATIONS}

\section{Acknowledgement}

The authors would like to thank the Research Directorate of Gadjah Mada University for support funding in this systematic review.

\section{Conflict of interest}

No conflict of interest is associated with this work.

\section{Contribution of authors}

We declare that the work described in this study was conducted by all authors named in this article and that all liabilities arising from claims related to the content of this article will be borne by the authors. YN conceptualized and coordinated the research and drafted the article. DW, FR, and NMY optimized the study design, ensured that all elements of the research protocol were realized in the preparation of the articles, provided inputs on the research design, and reviewed the contents of the manuscript. All authors have read and approve of the final version of this manuscript.

\section{Open Access}

This is an Open Access article that uses a funding model which does not charge readers or their institutions for access and distributed under the terms of the Creative Commons Attribution License (http://creativecommons.org/licenses/by/ 4.0) and the Budapest Open Access Initiative (http://www.budapestopenaccessinitiative.org/rea d), which permit unrestricted use, distribution, and reproduction in any medium, provided the original work is properly credited.

\section{REFERENCES}

1. Wasserman M. Primary care for older adults: models and challenges. New York: Springer Berlin Heidelberg; 2017; $p 166$.

2. Jin M, Naumann $T$, Regier L, Bugden S, Allen $M$, Salach L, Chelak K, Blythe N, Gagnon A, Dolovich L. A Brief Overview of Academic Detailing in Canada: Another Role for Pharmacists. Can Pharm J Rev Pharm Can 2012; 145(3): 142-146.

3. Loganathan $M$, Singh $S$, Franklin BD, Bottle A, Majeed A. Interventions to optimise prescribing in care homes: systematic review. Age Ageing 2011; 40(2): 150-162.

4. Moss JM, Bryan WE, Wilkerson LM, King HA, Jackson GL, Owenby RK, Van Houtven $C H$, Stevens $M B$, Powers J, Vaughan $\mathrm{CP}$, et al. An Interdisciplinary

Trop J Pharm Res, July 2020; 19(7): 1532 
Academic Detailing Approach to Decrease Inappropriate Medication Prescribing by Physician Residents for Older Veterans Treated in the Emergency Department. J Pharm Pract 2019; 32(2): 167-174.

5. Wood K, Gibson F, Radley A, Williams B. Pharmaceutical care of older people: what do older people want from community pharmacy? Older people's opinions of community pharmacy. Int J Pharm Pract 2015; 23(2): 121-130.

6. Flanagan PS, Barns A. Current perspectives on pharmacist home visits: do we keep reinventing the wheel? Integr Pharm Res Pract 2018; 7: 141-159.

7. Tietze KJ. Clinical skills for pharmacists: a patientfocused approach. 3rd ed. Missouri: Elsevier Mosby; 2012. $200 p$.

8. Muin D, Kristina SA, Prabandari YS, Satibi S. Factors Affecting Pharmacist's Performance Based on Motivation Theory: A Systematic Review. Glob J Health Sci 2019; 11(3): 13-22.

9. Roberts MS, Stokes JA, King MA, Lynne TA, Purdie DM, Glasziou PP, Wilson DAJ, McCarthy ST, Brooks GE, de Looze FJ, et al. Outcomes of a randomized controlled trial of a clinical pharmacy intervention in 52 nursing homes. Br J Clin Pharmacol 2001; 51(3): 257-265.

10. Krska J, Cromarty JA, Arris F, Jamieson D, Hansford D, Duffus PR, Downie G, Seymour DG. Pharmacist-led medication review in patients over 65: a randomized, controlled trial in primary care. Age Ageing 2001; 30(3): 205-211.

11. Lim WS, Low HN, Chan SP, Chen HN, Ding YY, Tan TL. Impact of a pharmacist consult clinic on a hospitalbased geriatric outpatient clinic in Singapore. Ann Acad Med Singapore 2004; 33(2): 220-227.

12. Phelan EA, Balderson B, Levine M, Erro JH, Jordan L, Grothaus L, Sandhu N, Perrault PJ, LoGerfo JP, Wagner EH. Delivering effective primary care to older adults: a randomized, controlled trial of the senior resource team at group health cooperative. J Am Geriatr Soc 2007; 55(11): 1748-1756.

13. Denneboom W, Dautzenberg MGH, Grol R, De Smet PAGM. Treatment reviews of older people on polypharmacy in primary care: cluster controlled trial comparing two approaches. $\mathrm{Br} \mathrm{J}$ Gen Pract 2007; 57(542): 723-731.

14. Gillespie U, Alassaad A, Hammarlund-Udenaes M, Mörlin $C$, Henrohn $D$, Bertilsson $M$, Melhus $H$. Effects of pharmacists' interventions on appropriateness of prescribing and evaluation of the instruments' (MAl, STOPP and STARTS') ability to predict hospitalization-analyses from a randomized controlled trial. PLOS ONE 2013; 8(5): e62401.

15. Gillespie $U$, Alassaad A, Henrohn D, Garmo $H$, Hammarlund-Udenaes $M$, Toss $H$, Kettis-Linblad $A$,
Melhus H, Morlin C. A Comprehensive Pharmacist Intervention to Reduce Morbidity in Patients 80 Years or Older: A Randomized Controlled Trial. Arch Intern Med 2009; 169(9): 894-900.

16. Richmond S, Morton V, Cross B, Wong CK, Russel I, Philips Z, Miles J, Hilton A, Hill G, Farrin A, et al. Effectiveness of shared pharmaceutical care for older patients: RESPECT trial findings. Br J Gen Pract 2010; 60(570): e10-e19.

17. Cullinan S, O'Mahony D, Byrne S. Use of an e-Learning Educational Module to Better Equip Doctors to Prescribe for Older Patients: A Randomised Controlled Trial. Drugs Aging 2017; 34(5): 367-374.

18. McNab D, Bowie $P$, Ross A, MacWalter G, Ryan $M$, Morrison J. Systematic review and meta-analysis of the effectiveness of pharmacist-led medication reconciliation in the community after hospital discharge. BMJ Qual Saf 2018; 27(4): 308-320.

19. Silva $R$ de OS, Macêdo LA, Santos GA dos, Aguiar PM, de Lyra DP. Pharmacist-participated medication review in different practice settings: Service or intervention? An overview of systematic reviews. Hills RK, editor. PLOS ONE 2019; 14(1): e0210312.

20. Dunning $T$, editor. Diabetes education: art, science, and evidence. West Sussex: Wiley-Blackwell; 2013. 184 p.

21. World Health Organization, Regional Office for SouthEast Asia. Comprehensive community and home-based health care model. New Delhi: World Health Organization, Regional Office for South-East Asia; 2004. $46 p$.

22. Fischer MA. Academic Detailing in Diabetes: Using Outreach Education to Improve the Quality of Care. Curr Diab Rep [Internet] 2016; 16(10): 1-6. $23 . \quad$ Schmidt-

Mende K, Andersen M, Wettermark B, Hasselström J. Educational intervention on medication reviews aiming to reduce acute healthcare consumption in elderly patients with potentially inappropriate medicines- $A$ pragmatic open-label cluster-randomized controlled trial in primary care. Pharmacoepidemiol Drug Saf 2017; 26(11): 1347-1356.

23. Hennessy S, Leonard CE, Yang W, Kimmel SE, Townsend RR, Wasserstein AG, Ten Have TR, Bilker WB. Effectiveness of a Two-Part Educational Intervention to Improve Hypertension Control: A ClusterRandomized Trial. Pharmacotherapy 2006; 26(9): 1342 1347.

24. Nishtala PS, McLachlan AJ, Bell JS, Chen TF. Psychotropic Prescribing in Long-Term Care Facilities: Impact of Medication Reviews and Educational Interventions. Am J Geriatr Psychiatry 2008; 16(8): $621-$ 632. 